\title{
11. CRETACEOUS BENTHONIC FORAMINIFERA, LEG 20, DEEP SEA DRILLING PROJECT
}

\author{
Valeri A. Krasheninnikov, Geological Institute of the Academy of Sciences of the USSR, Moscow
}

During the course of Leg 20, Cretaceous deposits were penetrated in Holes 194, 195, 195A, 195B, 196, 197, 198A, 199, three of which (195B, 196, 198A) contain poor assemblages of benthonic foraminifera. In Hole 195B, they are of Early Cretaceous and in Holes 196 and 198A, of Late Cretaceous age.

\section{LOWER CRETACEOUS}

Lower Cretaceous deposits consist of white, gray, yellow, and greenish chalk; siliceous porcelaneous limestones; marls with intercalations of radiolarian claystones; and red, brown, pinkish, black, and gray cherts (Holes 195, 195A, 195B, 196). Nannofossils and radiolarians are the predominant microfossils in these sediments. Identifiable representatives of calcareous nannofossils constitute at least 10 to $15 \%$ of the sediment and indicate an assignment to the lowermost part of the Neocomian (Valanginian, early Hauterivian) (see Nannofossil Biostratigraphy, Hekel, this volume). The radiolarians are usually preserved and suggest an early Cretaceous age for these sediments (see Foreman, this volume).

Benthonic foraminifera occur much less frequently than nannoplankton and Radiolaria and were found only in the limestones of Hole 195B (Core 3). Included are both calcareous and agglutinated species; they are characteristically small and not abundant. The most common species in the assemblages are: Lenticulina kugleri Bart., Bett., and Bolli; L. muensteri (Roem.); L. crassa (Roem.); L. subulata (Reuss); Frondicularia hastata Roem.; Lingulina praelonga ten Dam; Spirillina neocomiana Moull.; Dorothia praeoxycona Moull.; D. zedlerae Moull.; D. ouachensis (Sig.); and $D$. aff. hauteriviana (Moull.). They are accompanied by rare specimens of a number of other species of Lenticulina, Dentalina, Lagena, Nodosaria, Ramulina, Lingulina, Frondicularia, and Pseudonodosaria. Minute, poorly preserved planktonic foraminifera (Gubkinella sp.) were found together with the benthonic species.

The above assemblage of benthonic foraminifera from Hole 195B has much in common with the associations at Sites 49 and 50 of Leg 6 on the western slope of Shatsky Rise. The age of the Site 49 and 50 deposits with Lenticulina kugleri, L. ouachensis, Frondicularia hastata, Dorothia praeoxycona, etc., was originally interpreted as Late Jurassic (Tithonian)-Early Cretaceous (Neocomian) (Fisher et al., 1970). Subsequent study of the benthonic foraminifera of Holes 49 and 50 by Douglas and Moullade (1972) led to the conclusion that they are somewhat younger-late Hauterivian-early Barremian.

There is also a discrepancy in defining the age of deposits based on benthonic foraminifera on the one hand (upper Hauterivian-lower Barremian) and nannoplankton on the other (Valanginian-early Hauterivian). However, it should be kept in mind that the zonal scale of the Neocomian based on nannoplankton, and the stratigraphic subdivision of the Neocomian of the northwestern part of the Pacific area based on benthonic foraminifera, have not been sufficiently perfected. This seems to be the cause of the contradiction in age of these deposits, though the discrepancy is not large.

Thus, limestones, marls, and radiolarian claystones with interbeds of variegated flints of Neocomian age are developed over a considerable area of the extreme northwestern Pacific. They have been penetrated by holes, not only on the western slope of the Shatsky Rise, but also on the abyssal plain towards the west and southwest. At present, the depth of the ocean exceeds 6000 meters here (Holes 195B, 196). Calcareous sediments with flinty interlayers seem to occur on basaltic basement (Hole 197) and underlie pelagic red clays. The deposition of carbonate was naturally proceeding above the level of carbonate compensation; thus, water depth in the Neocomian must have been considerably less than at present.

Douglas and Moullade (1972) believe, on the basis that benthonic foraminifera from the Neocomian deposits of the Shatsky Rise display a great similarity with the shallow-water microfauna of the Neocomian of Europe, that the depths of the Neocomian Pacific Ocean were measured in hundreds rather than thousands of meters. However, the composition, morphological peculiarities and preservation of microfossils from the limestones and flints of Hole 195B testify to an abyssal origin for these rocks. Among foraminifera, representatives of the Lagenidae are numerically predominant; the tests of calcareous and agglutinated foraminifera are thin-walled and small; and the walls of agglutinated foraminifera are fine-grained. On this basis, water depth should be estimated to have been on the order of at least $1-1.5 \mathrm{~km}$.

The limestones, marls, and variegated flints of the Neocomian of "the northwestern part of the Pacific ocean resembles, in lithological and micropaleontological character, abyssal limestones, radiolarites, and flints of the Mesozoic (Triassic, Jurassic, Lower Cretaceous) of the Alpine belt. As it is known, many workers regard these deposits as oceanic, formed on basaltic crust of an oceanic type.

\section{UPPER CRETACEOUS}

The Upper Cretaceous deposits of Holes 196 and 198A that contain benthonic foraminifera are represented by a lithology quite distinct from that of the Lower Cretaceous. To the Upper Cretaceous belong very stiff, homogeneous, dark brown and reddish yellow zeolitic and zeoliticlimonite clays and silty clays. The deposition of these abyssal pelagic sediments occurred below the carbonate 
compensation depth, evidently at depths similar to the present day depth of the Pacific Ocean in the region of Holes 196 and 198A (about $6000 \mathrm{~m}$ and over).

The zeolitic abyssal clays are barren of calcareous fossils, though sporadic corroded casts of Globigerinelloides, Hedbergella, and Heterohelix were found. The microfauna consists of Radiolaria (usually poorly preserved) and agglutinated foraminifera. The latter are of great interest, though they were observed relatively sporadically.

Benthonic agglutinated foraminifera were found in the following samples. Samples from Hole 196: Core 2, Section 1 (18-20, 30-32, 38-40, 64-66, 107-109, 136-138); Core 2, Section $2(32-34,73-75,122-124)$; Core 2 Section 3 (18-20, 88-90, 120-122); Core 2, Section 4 (20-22, 66-68, 110-112); Core 2, Section 5 (16-18, 74-76, 129-131); and Core 2, Section $6(32-34,52-54,121-123)$. Samples from Hole 198A: Core 3, Section 1 (138-140); Core 3, Section 2 (90-92); Core 3, Section 3 (4-6, 145-147); Core 3, Section 4 (53-55); Core 3, Section 5 (55-57, 108-110); Core 3, Section 6 (90-92); Core 3, CC; Core 4, Section 1 (116-118, 138-140, 147-149); Core 4, Section 2 (140-142); and Core 4 , Section $3(20-22,60-62,86-88,104-106,143-145)$. Many samples of the clays lack agglutinated foraminifera.

The assemblages of agglutinated foraminifera are not diverse, comprising 25 species. Only 20 species, however, are represented by relatively numerous specimens. These belong to the families Ammodiscidae (species of Ammodiscus and Glomospira), Trochamminidae (species of Praecystammina), Textulariidae (species of Plectorecurvoides, Bolivinopsis, Pseudobolivina), and especially the family Lituolidae (species of Haplophragmoides, Labrospira, and Paratrochamminoides). Primitive agglutinated foraminifera from the families Astrorhizidae, Saccamminidae, and Hormosinidae are practically absent.

Agglutinated benthonic foraminifera from the present samples differ sharply from the species of Haplophragmoides, Labrospira, Plectorecurvoides, and Paratrochamminoides, that have been described from the Lower and Upper Cretaceous of Australia (Crespin, 1953, 1963), Japan (Yoshida, 1963; Takayanagi, 1960), Alaska (Tappan, 1957), California (Trujillo, 1960; Sliter, 1968), the Gulf Coast and Caribbean region (Cushman, 1946; Cushman, Deaderick, 1944; Cushman, Jarvis, 1932; Galloway, Morrey, 1931, Frizzel, 1954), some European countries Poland (Geroch, 1960, 1962, 1966), Czechoslovakia (Hanzlikova, 1969, 1972, 1973; Sheibnerova, 1961, 1968), Rumania (Neagu, 1962, 1968, 1970), Austria (Noth, 1951), USSR (Myatlyuk, 1970; Plotnikova, 1967)- and the Asiatic part of the USSR (West Siberian lowland) (Alekseichik-Mitskevich, Subbotina et al., 1964; Podobina, 1966).

Almost all the species of Haplophragmoides, Plectorecurvoides, and Paratrochamminoides seen in the present study are new. They are accompanied by a species of the new genus Praecystammina. Only some species of primitive Ammodiscus and Glomospira, as well as some species of Haplophragmoides and Bolivinopsis, may be attributed (with some doubt) to already known species.

On the whole, the assemblage of agglutinated foraminifera from the pelagic clays of Holes 196 and 198A differs considerably from associations of benthonic foraminifera described from Lower and Upper Cretaceous deposits exposed on land. It is very likely that this difference is a result of the abyssal environment of deposition. Analogues of the red zeolitic pelagic clays on land are practically absent; also absent are the peculiar assemblages of abyssal benthonic foraminifera that were found for the first time in the clays penetrated in Holes 196 and 198A.

The abyssal environment has left its mark on morphological peculiarities of the agglutinated foraminifera. They are all characterized by small test size (usually $0.20-0.30 \mathrm{~mm}$ ) and extremely thin walls. The tests are so fragile that they can be broken even by a slight touch of the brush.

The thin wall of specimens of Haplophragmoides, Praecystammina, Labrospira, Plectorecurvoides, and Pseudobolivina appears completely homogeneous, fine grained, and with a smooth surface. When moistened with water, the wall becomes semitransparent and the inner whorls and chambers can be observed. As to its outer appearance, the wall of the above agglutinated foraminifera resembles the granular wall of calcareous nonionids and cassidulinids.

In specimens of Glomospira and Paratrochamminoides, the walls are similarly homogeneous, fine grained, and with a smooth surface, but they are thicker. They resemble the porcelaneous walls of calcareous miliolids. However, in some specimens of Paratrochamminoides, the walls are very thin, and when moistened with water, they become semitransparent.

The question thus arises of whether the wall of benthonic foraminifera from abyssal clays is agglutinated or secreted. The answer awaits further study such as investigation of the microstructure of the wall by electron microscopy. It is quite probable that the homogeneity of the wall can be explained by the small size of agglutinated material (components of red oceanic clays).

Some species of Haplophragmoides, Bolivinopsis, and Pseudobolivina from the abyssal clays of Holes 196 and 198A have general morphological similarity with representatives of these genera from Cretaceous deposits of America and Europe, but they differ considerably in being $1 / 2$ to $1 / 4$ as large, and in having a homogeneous (not coarse-grained, agglutinated) test wall. Unfortunately, it cannot be determined at present whether the former are independent taxonomic units (species) or whether they should be regarded as ecological (abyssal) variants of species previously described from relatively shallow-water deposits.

The above assemblages also contain specimens of Plectorecurvoides and Bolivinopsis, and sporadic casts of Globigerinelloides and Hedbergella, which testify to the Cretaceous age of the deposits; the presence of Bolivinopsis most likely indicates a Late Cretaceous age for the zeolitic clays. The accompanying radiolarians suggest placement within the Santonian-Campanian (probably lower Campanian) (see Foreman, this volume).

It is doubtless that the above complex of agglutinated foraminifera will be found in other regions of the Pacific ocean as well, thus becoming of considerable importance for age determination and for the correlation of abyssal clay sediments that, in general, are poor in organic remains. 
Therefore, some of the most important species of agglutinated benthonic foraminifera are described below. ${ }^{1}$

\section{SYSTEMATIC PALEONTOLOGY}

\section{Family LITUOLIDAE}

\section{Genus HAPLOPHRAGMOIDES Cushman, 1910}

Typical representatives of this genus are characterized by a planispirally coiled, usually completely involute test with a slit-like equatorial interiomarginal aperture at the base of a septal surface (Loeblich and Tappan, 1964). Species of Haplophragmoides with a slightly evolute test are rarely observed.

In Upper Cretaceous deposits penetrated in Holes 196 and 198A, involute representatives of Haplophragmoides ( $H$. molestus sp. nov., $H$. decussatus sp. nov., and $H$. breviculus sp. nov.) are rare. Specimens of Haplophragmoides with a slightly evolute $(H$. biumbilicatus sp. nov., $H$. perexplicatus sp. nov., and $H$. pervagatus sp. nov.) and distinctly evolute ( $H$. multicamerus sp. nov., $H$. constrictus sp. nov., and $H$. fraudulentus sp. nov.) test are much more common.

The erection of a new genus or subgenus for these evolute specimens of Haplophragmoides should be regarded as ill advised. Evolute representatives of Haplophragmoides are known from deposits of various ages (from Jurassic to Quaternary). In Upper Cretaceous deposits of the northwestern part of the Pacific Ocean, as noted above, not only involute and evolute species of Haplophragmoides, but also the species with intermediate morphology (weakly evolute) were seen. Thus, no clear distinction between the involute and evolute forms is possible.

It is likely that diagnosis of the genus Haplophragmoides should be extended to include both involute and evolute planispiral forms with an interiomarginal slit-like aperture. It is possible that the wide development of evolute and slightly evolute representatives of Haplophragmoides in pelagic zeolitic clays is related to the deep-water environment.

Well-developed evolute specimens of Haplophragmoides $(H$ multicamerus, $H$. constrictus, $H$. fraudulentus) resemble, to a certain extent, species of the genus Trochamminoides. They differ, however, in regular coiling in one plane, a regular partition of whorls into chambers (including the initial part), increase in height of the whorls, and the presence of a low, slit-like aperture.

Haplophragmoides multicamerus sp. nov. (Plate 1, Figures 1a,b, 2a,b)

Holotype: No. 4011/1 (Figure 1a,b), Hole 196, Core 2, Section 1 (38-40), Pacific ocean, Upper Cretaceous (Santonian-Campanian). Paratype No. 4011/2 (Fig. 2a,b), Hole 198A, Core 3, Section 6 (90-92), Pacific ocean, Upper Cretaceous (Santonian-Campanian).

Description. Test small, clearly evolute, consisting of 2 to $2 \frac{1}{2}$ whorls, strongly compressed, with a rounded peripheral margin. In the process of growth the height of the whorl becomes gradually and rather rapidly larger. In this relation, when looking from the lateral side, the form of the test is oval, with a slightly lobate outline. The umbilicus is broad, but not deep; lateral sides are flat concave. In the last whorl there are 9 to 11 chambers, trapeziform, slightly convex. Septal sutures are straight, radial, slightly deepened. The apertural surface is slightly convex, oval. A low, slit-like aperture is at the base of this surface. The wall is siliceous, glassy,

\footnotetext{
${ }^{1}$ The holotypes of new species and originals of other species of foraminifera described in this work are kept in the Micropaleontological laboratory of the Geological Institute of the Academy of Sciences of the USSR, Moscow, Collection No. 4011. The photographs of foraminifera have been done by A. I. Nikitin, retouched by A. N. Makarevich. The author expresses acknowledgment.
}

bright, homogeneous (when magnified 150 times separate grains are not visible). Dimensions: diameter-0.13-0.28 mm, thickness-0.5$0.9 \mathrm{~mm}$.

Remarks: Morphological features of this peculiar species are rather constant. Only dimensions of the test vary considerably (remaining less than $0.3 \mathrm{~mm}$ ); umbilicus is sometimes small.

Evolute species of Haplophragmoides with numerous chambers in the last whorl have been established in the Jurassic ( $H$. barrowensis Tapp.), Lower Cretaceous (H. barremicus Myat1.), Upper Cretaceous ( $H$. fraseri Wick., $H$. inflata Gauger). The last of these shows certain similarity with the above species, differing in a narrow, rounded peripheral margin, insignificant increase of the height of whorls, and short and wide subsquare chambers.

Stratigraphic range. The Upper Cretaceous (SantonianCampanian) of the northwestern part of the Pacific Ocean, Holes 196 and $198 \mathrm{~A}-$ frequent.

\section{Haplophragmoides fraudulentus sp. nov. (Plate 1, Figures 9a,b)}

Holotype: No. 4011/3; Hole 196, Core 2, Section 1 (18-20), Pacific Ocean; Upper Cretaceous (Santonian-Campanian).

Description: The test is small, clearly evolute, very strongly compressed from the lateral sides, with a rounded peripheral margin; the spire usually consists of two whorls. In the process of growth, the height of the whorls increases slightly. When looking from the lateral side, the test is rounded, with lobulate contours. From the periphery, the test looks narrowly oval. The umbilicus is broad but flat; lateral sides are flat concave. The last whorl contains six to seven chambers, spherical, convex. They are separated by deep septal sutures, almost radial at the beginning of the last whorl, and slightly curved-at its end. The apertural surface is convex, low-oval, almost rounded. At its base there is a small slit-like aperture. The wall is siliceous, glassy, shiny, homogeneous, evidently agglutinated, but when magnified 150 times practically no grains can be observed. Dimensions: diameter $-0.17-0.23 \mathrm{~mm}$; thickness $-0.05-0.7 \mathrm{~mm}$.

Remarks: This species differs considerably from other species of Haplophragmoides owing to its delicate planispiral test with spherical chambers and glassy wall. It is rather reminiscent of representatives of some planktonic foraminifera (Globigerinelloides, for example), this being responsible for the name of the species (fraudulentus meaning "deceptive").

Stratigraphic range: The Upper Cretaceous (Santonian-Campanian) of the northwestern part of the Pacific Ocean, Holes 196 and $198 \mathrm{~A}$-common.

\section{Haplophragmoides constrictus sp. nov. (Plate 1, Figures 5a,b)}

Holotype: No. 4011/4; Hole 196, Core 2, Section 1 (30-32), Pacific Ocean; Upper Cretaceous (Santonian-Campanian).

Description: The test is small to medium sized, planispiral, distinctly evolute (the first chamber can occasionally be well seen), strongly compressed from the lateral sides, with a rounded peripheral margin. The spire consists of two to two and a half whorls, their height increasing very slowly in the process of growth. When looking from the lateral side, the test is rounded with a slightly lobulate contour; from the periphery it looks narrowly oval. The lateral sides of the test are planiconcave; their central parts are occupied by a broad and shallow umbilicus. The last whorl consists of six to seven chambers that are low trapeziform, moderately convex, and rather broad. They are separated by slightly concave, straight septal sutures. The apertural surface is convex, rounded; a low slit-like aperture occurs at its base. The wall is siliceous, smooth, bright, glassy, and homogeneous (when magnified 150 times, separate grains can not be observed). Dimensions: diamtere-0.33$0.43 \mathrm{~mm}$; thickness $-0.12-0.17 \mathrm{~mm}$.

Remarks: There is a remote morphological similarity only with some recent species of Haplophragmoides (H. membranaceum Högl., $H$. columbiense evolutum Cushm. and McCull.). The species concerned differs from $H$. fraudulentus sp. nov. by squeezed trapeziform (not spherical) chambers, less deepened septal sutures, and less lobulate contour of the test. 
Stratigraphic range: Upper Cretaceous (Santonian-Campanian); Pacific Ocean. Holes 196 and 198 A-common.

\section{Haplophragmoides biumbilicalis sp. nov.}

(Plate 1, Figures 3a,b, 4)

Holotype: No. 4011/5 (Figures 3a,b); Hole 198A, Core 3, CC; Upper Cretaceous (Santonian-Campanian); Pacific Ocean. Paratype No. 4011/6 (Figure 4); Hole 198A, Core 3, Section 6 (90-92); the same age.

Description: The test is very small, planispiral, slightly evolute, consists of one and one half to two whorls of a low spire. When looking from the side, the test is rounded, with a slightly lobulate contour; from the periphery the test looks broadly oval, the peripheral margin being widely rounded. In the central part of the lateral sides, there is a small, but deep umbilicus, having a conical form. The umbilicus is separated from the rest of the test by a distinct bend of the wall. The last whorl contains five to six low chambers; their form on the lateral side is approximately triangular. The chambers are moderately convex and separated by slightly deepened, straight septal sutures. The apertural surface is convex, low, broadly oval with an arch-shaped aperture at its base; it is usually centrally located and does not stretch to the umbilical ends of the chamber. The wall is siliceous, glassy, smooth, glittering, homogeneous (when magnified 150 times, grains of the wall are not visible). Dimensions: diameter-0.15-0.23 mm; thickness-0.13-0.15 mm.

Remarks: One of the variable features of this species is the structure of the umbilical area. In some specimens and the holotype, the umbilicus is small, very deep, and the initial whorl is hardly visible. In other specimens, the umbilicus is more open, and the first chamber and initial whorls can be easily seen. The latter type is somewhat more common.

This species differs considerably from other species of Haplophragmoides; it is more similar (as to the form of the test) to Neogene representatives of the genus Melonis (with a calcareous test). A remote resemblance is observed with Upper Cretaceous Haplophragmoides flagleri Cushm. and Hedb. and Recent $H$. veleronis Cushm. and $\mathrm{McC}$ ull. The species concerned differs from them in a smaller number of chambers, their form, different structure of the umbilicus and some other features.

Stratigraphic range: Upper Cretaceous (Santonian-Campanian); northwestern part of the Pacific Ocean, Holes 196 and $198 \mathrm{~A}-$ relatively rare.

\section{Haplophragmoides pervagatus sp. nov.}

(Plate 1, Figures 7a,b)

Holotype: No. 4011/7; Hole 196, Core 2, Section 1 (64-66); Upper Cretaceous (Santonian-Campanian); Pacific Ocean.

Description: The test is small, planispiral, slightly evolute; chambers of initial whorls are slightly visible in the umbilical area. When looking from the side, the test is rounded, with slightly lobulate contour; from the periphery, the test is compressed, oval, with a rounded peripheral margin. In the central part of the lateral sides, there is a small, shallow umbilicus. The lateral sides are slightly concave, almost flat. The whorls grow slowly and gradually, therefore, the last chamber noticeably embraces the penultimate whorl. The final whorl contains six chambers, slightly convex, flattened, trapeziform on the lateral sides, and wide. Septal sutures are straight and slightly deepened. The apertural surface is convex and oval, with a low, long, slit-like aperture at its base. The wall is siliceous, glassy, smooth, glittering, and homogeneous (when magnified 150 times no separate grains can be observed). Dimensions: diameter-0.25-0.35 mm; thickness-0.13-0.15 mm.

Remarks: Morphological features of the species are rather constant, with some variation in the size of the umbilicus. The species is somewhat similar to some slightly evolute representatives of Haplophragmoides $(H$. howardense Stelck and Wall, $H$. fraseri Wick., $H$. carlilensis Fox), from Cretaceous deposits. It differs from these by a smaller number of chambers in the final whorl, broader chambers, a homogeneous wall, and smaller size.

Stratigraphic range: Upper Cretaceous (Santonian-Campanian); northwestern part of the Pacific Ocean, Holes 196 and $198 \mathrm{~A}$-relatively rare species.
Haplophragmoides perexplicatus sp. nov. (Plate 1, Figures 6a,b)

Holotype: No. 4011/8; Hole 198A, Core 4, Section 2 (140-142); Upper Cretaceous (Santonian-Campanian); Pacific Ocean.

Description: The test is small, planispiral, slightly evolute, a small part of the penultimate whorl being visible in the umbilical area. When looking from the lateral side, the test is broadly oval, elongated in the direction of coiling, with a slightly lobulate contour; from the periphery, the test looks strongly squeezed, narrowly oval, with a rounded peripheral margin. The lateral sides are flat, slightly concave; in their central part there is a minute umbilicus. The test is characterized by a rapid growth of whorls-the final chamber only touches the previous whorl. The final whorl contains six to seven chambers, slightly convex, relatively narrow; on the lateral side of the test their form is approximately triangular. The final chamber is elongated in the direction of coiling and stretches beyond the general contour of the test. The septal sutures are straight and slightly deepened. The apertural surface is convex, oval, with a low, slit-like aperture at the base. The wall is siliceous, glassy, smooth, bright, and homogeneous (when magnified 150 times no separate grains can be observed). Dimensions: diameter0.22-0.30 mm; thickness-0.07-0.10 mm.

Remarks: The above species is similar to $H$. pervagatus sp. nov. differing in a rapid increase of the height of whorls, more narrow chambers, and the final elongated chamber protruding beyond the general contour of the test.

A remote resemblance can be observed with $H$. eocalcula Stelck and Wall from Cenomanian deposits of west Canada. However, this species is distinguished by a coarse, arenaceous wall (grains averaging between $0.04-0.05 \mathrm{~mm}$ ), very faint sutures, and obscure chambers.

Stratigraphic range: Upper Cretaceous (Santonian-Campanian); northwestern part of the Pacific Ocean, Holes 196 and $198 \mathrm{~A}$-common.

\section{Haplophragmoides molestus sp. nov.} (Plate 1, Figures 8a,b)

Holotype: N-4011/9; Hole 198A, Core 4, Section 1 (138-140); Upper Cretaceous (Santonian-Campanian); Pacific Ocean.

Description: The test is small, planispiral, involute, moderately compressed from the lateral sides. When looking from the side, the test is almost perfectly round, with hardly noticeable lobulation; from the periphery, it is oval, with a broadly rounded peripheral margin and flat, concave lateral sides. The umbilicus is small and flat; chambers are almost united in the center and inner whorls are not observed. Whorls increase slowly and regularly. The last whorl contains five to six tightly arranged chambers, convex, with flattened lateral sides and broad. Septal sutures are weakly deepened and straight. The septal face is convex, broadly oval, with a low, arch-like aperture at its base. This aperture does not stretch to the lateral sides of the test, being limited to the equatorial part of the apertural surface. The wall is siliceous, glassy, smooth, bright, homogeneous (when magnified 150 times, no separate grains are visible). Dimensions: diameter-0.25-0.32 mm; thickness-0.15$0.20 \mathrm{~mm}$.

Remarks: There exists considerable morphological similarity with $H$. kirki Wickend. from the Upper Cretaceous Bearpaw shale of Canada (Alberta), which is also characterized by a small test with a finely arenaceous, smooth wall. The species concerned is distinguished by a broadly rounded peripheral margin, flat concave lateral sides, and a convex, high, apertural surface.

Stratigraphic range: Upper Cretaceous (Santonian-Campanian); northwestern part of the Pacific Ocean, Holes 196 and 198A-rare.

\section{Haplophragmoides decussatus sp. nov. (Plate 2, Figures 3a,b)}

Holotype: N 4011/10; Hole 196, Core 2, Section 2 (122-124); Upper Cretaceous (Santonian-Campanian); Pacific Ocean.

Description: Test small, planispiral, completely involute, weakly compressed from the lateral sides. When looking from the side, the test is almost correctly rounded, with an even, faintly lobulate contour; from the periphery, it is broadly oval, with a broadly rounded peripheral margin. Lateral sides are convex. Umbilical ends 
of chambers reach the center; the last chamber occasionally covers a little of the preceding chambers. The umbilicus is exceedingly small (practically absent). Whorls are very low and increase slowly. The last whorl consists of four chambers having cruciform arrangement. Chambers are tightly coiled, moderately convex, flattened on lateral sides of the test, subspherical, and broad. Septal sutures are straight and weakly depressed. The apertural face is low, moderately convex, and arcuate in connection with strong involution of the test. A comparatively large (taking into account the size of the test itself) arch-like aperture is located at the base of the apertural face. The wall is siliceous, glassy, very thin, smooth, glittering, and homogeneous (when magnified 150 times, no separate grains are observed). Dimensions: diameter-0.20-0.25 mm; thickness -0.15 $0.18 \mathrm{~mm}$.

Remarks: Characteristic features of this species-strong involution of the test, small number of chambers (4), and their cruciform arrangement-distinguish $H$. decussatus from other representatives of this genus. There is a remote resemblance to $H$. longifissus Israel. from the upper Paleocene-lower Eocene deposits of the Lodo formation (California). The latter is distinguished clearly by a large test (diameter $0.78 \mathrm{~mm}$ ), coarsely arenaceous, roughly cemented wall, and in visible septal lines.

Stratigraphic range: Upper Cretaceous (Santonian-Campanian); northwestern part of the Pacific Ocean, Holes 196 and 198A-rare.

\section{Haplophragmoides breviculus sp. nov.} (Plate 2, Figures 12a,b)

Holotype: N 4011/11; Hole 198A, Core 3, Section 6 (90-92); Upper Cretaceous (Santonian-Campanian); Pacific Ocean.

Description: Test exceedingly small, subspherical, planispiral, and completely involute. When looking from the side, the test is evenly rounded, with an even (not lobulate) contour; from the periphery, it is broadly oval, inflated, approaching circular, with a broadly rounded peripheral margin. Lateral sides are strongly convex. Coiling is very tight; umbilical ends of chambers reach the center and the umbilical deepening is practically absent. Whorls are relatively low, and increase gradually. The last whorl consists of six to seven chambers, moderately convex, with a flattened, narrow, surface; from the lateral sides they are triangular. Septal sutures are straight, flat, and poorly visible. The apertural face is low, weakly convex, and reniform; a long, low slit-like aperture is located at its base. The wall is siliceous, glassy, glittering, smooth, very thin, semitransparent, and homogeneous (when magnified 150 times, no separate grains are observed). Dimensions: diameter-0.13-0.17 mm; thickness is practically equal to diameter $-0.14-0.17 \mathrm{~mm}$.

Remarks: The species described is similar to some Cretaceous and Cenozoic species of Haplophragmoides; however, the unusually small dimensions and thin, semitransparent, homogeneous wall distinguish it from any previously known species of this genus. Haplophragmoides breviculus rather resembles representatives of Melonis (or Nonion) with a thin, calcareous, granular wall.

Stratigraphic range: Upper Cretaceous (Santonian-Campanian); northwestern part of the Pacific Ocean, Holes 196 and 198A-rare.

\section{Genus LABROSPIRA Höglund, 1947}

This genus is similar to Cribrostomoides Cushman, 1910 and is very often treated as a junior synonym of the latter (Orlov et al., 1959; Loeblich and Tappan, 1964). Labrospira is distinguished from Cribrostomoides by a more rapid increase in the height of the whorl, a relatively compressed (from lateral sides) test and a slit-like (or oval) areal aperture above the base of the apertural face. The genus Cribrostomoides is characterized by a sphaerical inflated test, very low whorls, and an aperture which in adult specimens consists of a row of rounded areal openings above the base of the apertural face. Secondary distinguishing features of the genus Labrospira are as follows: mainly evolute test with a broad umbilical area, trapeziform chambers, and broad (double contoured) septal sutures.

In the zeolitic deep-water clays penetrated in Holes 196 and $198 \mathrm{~A}$, a species of agglutinated foraminifera has been met which resembles by its morphological features (a compressed oval test with the areal slit-like aperture above the base of the apertural surface) the genus Labrospira. This enables us to consider the genus Labrospira as an independent genus.
At the same time, the species of Labrospira under consideration differs from typical representatives of this genus by a strong involution of tests (the last chamber covers the umbilical area), thin septal sutures, chambers in the shape of irregular triangles or ovals. But, establishing a new generic taxon for agglutinated foraminifera in question does not seem to be well-grounded when validity of the genus Labrospira itself is subject to doubts.

\section{Labrospira pacifica sp. nov.}

(Plate 2, Figures 4a,b, 5a,b)

Holotype: N4011/12 (Figures 4a,b); Hole 196, Core 2, Section 1 (107-109); paratype N 4011/13 (Figures 5a,b), Hole 198A, Core 4, Section 1 (116-118); Upper Cretaceous (Santonian-Campanian); Pacific Ocean.

Description: Test small, lens-like, planispiral, completely involute, last chamber enveloping the umbilical area and umbilical ends of previous chambers. Test broadly oval or irregularly circular in lateral profile with even, or slightly lobulate contour; oval in axial profile, with convex lateral sides and rounded peripheral margin. Coiling tight; height of whorls increases slowly and uniformly. The last whorl consists of three to four chambers, moderately convex, with flattened lateral sides, relatively broad, irregularly triangular, irregularly oval or reniform shaped. Septal sutures are very thin, flat and strongly curved. The apertural surface is moderately convex, arch-like in form in response to a strong enveloping of the initial part of the last whorl. The aperture is areal, slit-like or oval, located in the lower part of the apertural face but above its base, occasionally bordered by a thin lip. The wall is siliceous, smooth, glassy, glittering, and homogeneous (when magnified 150 times no separate grains are observed). Dimensions: diameter $-0.20-0.30 \mathrm{~mm}$; thickness $-0.15-0.20 \mathrm{~mm}$.

Remarks: The following morphological features of this species are subject to variation: the form of the test-from lens-like to broadly lens-like; the form of the peripheral margin-from broadly rounded to narrow-rounded; degree of involution-from involute to strongly involute (the last chamber partially covers earlier chambers).

The species described, differs essentially from all other representatives of planispirally coiled Labrospira, Cribrostomoides, and Haplophragmoides. Disregarding the aperture, Labrospira pacifica resembles the genus Pullenia, but laterally compressed.

Stratigraphic range: Upper Cretaceous (Santonian-Campanian); northwestern part of the Pacific Ocean, Holes 196 and 198A-common.

\section{Family TEXTULARIIDAE}

\section{Genus PLECTORECURVOIDES Noth, 1952}

This extremely peculiar genus includes agglutinated foraminifera with a planispirally enrolled, biserial test. The aperture is usually not visible, but intercameral foramens are interiomarginal. The genus Plectorecurvoides can be treated as an agglutinated isomorph of the genus Cassidulina with a calcareous granular test, though the biserial arrangement of chambers of the former is not usually marked by that strict symmetry which is typical of the genus Cassidulina.

The problem of the taxonomic position of the genus Plectorecurvoides cannot be considered definitely solved. Noth (1952), the author of this genus, attributed it to the family Lituolidae. Loeblich and Tappan (1964) included Plectorecurvoides in the family Textulariidae and established the new (monotypic) subfamily Plectorecurvoidinae.

The genus Plectorecurvoides has usually been considered monotypic. Its holotype ( $P$. alternans Noth) was described from the Lower Cretaceous (Albian) deposits of Austria. P. alternans was subsequently found in the Albian stage of the Crimea, USSR (Gorbachik, in Guide book of the XII European Micropaleontological Colloquium, 1971) and in the Albian-Turonian deposits of Poland (Geroch, 1962, 1966). A full generic and specific synonym of Plectorecurvoides alternans is Globivalvulinella grossheimi Buk. from the Albian sediments of the northwestern Caucasus (Bukalova, 1957). A second species of the genus Plectorecurvoides ( $P$. irregularis) has been described from the Barremian-Cenomanian(?) deposits of Poland (Geroch, 1962). 
The genus Plectorecurvoides is thus represented by two species developed in the Lower-Upper Cretaceous (Barremian-Turonian) deposits of some European countries (Austria, Poland, Czechoslovakia, USSR). The occurrence of a new species of Plectorecurvoides in the Santonian-Campanian sediments of the northwestern part of the Pacific ocean extends considerably the geographic and stratigraphic range of this genus.

\section{Plectorecurvoides parvus sp. nov.}

(Plate 2, Figures 6a,b,c, 7a,b,c)

Holotype: N4011/14 (Figures 7a,b,c); Hole 196, Core 2, Section 5 (74-76); paratype N 4011/15 (Figures 6a,b,c); Hole 198A, Core 4, Section 1 (138-140); Upper Cretaceous (SantonianCampanian); Pacific Ocean.

Description: Test small, subsphaerical, inflated, slightly compressed from the lateral sides, planispirally coiled, consisting of two rows of alternating chambers (biserial). Usually, the rows of chambers are arranged roughly symmetrically relative to the equatorial plane of the test, and a zigzag sutural line is observed along the peripheral margin (Figures $7 \mathrm{a}, \mathrm{c}$ ); rarer deflection from symmetry is rather pronounced, and a sutural line between two adjacent rows of chambers has an irregular shape (Figures 6a,c). When looking from the side, the test is oval, with even or slightly lobulate contour; from the periphery, the test is broadly oval, with convex lateral sides and a broadly rounded peripheral margin. The height of whorls increases gradually. The last (outer) whorl contains 8-10 chambers (4-5 chambers on each side of the test). Chambers are moderately convex, compressed from the lateral sides, flattened, and variously shaped (irregularly oval, irregularly trapeziform, subtriangular). Septal sutures are flat, thin, sometimes indistinctly double-contoured, and poorly visible (they are better observed, when a test is placed in a drop of water). In this connection, the contours of chambers are also indistinct. The septal face is low-oval, convex; it consists of two chambers of adjacent rows (Figure 6c) or is almost completely occupied by one chamber, while only an insignificant portion of the second chamber, symmetrical to the first one, is visible (Figure 7c). The aperture is usually obscure; a foramen looks like a small rounded opening at the base of the apertural face of every chamber. The wall is agglutinated, siliceous, smooth, and homogeneous (when magnified 150 times, minute grains of equal size are indistinctly observed). Dimensions: diameter0.20-0.28 mm; thickness-0.18-0.25 mm.

Remarks: The following morphological features are variable: the shape of the test (spherical to weakly compressed from the lateral side), the character of biserial coiling (from symmetrical up to roughly symmetrical arrangement of two rows of chambers), the form of the sutural line between two rows of chambers along the peripheral margin (zigzag or very irregular).

The species described is distinguished from $P$. irregularis Geroch by a sphaerical test (the latter has a test compressed from the sides) and a more symmetrical biserial arrangement of chambers; it differs from $P$. alternans Noth by a smaller number of chambers in the last whorl, broad chambers (in $P$. alternans they are narrow oval), and a much smaller test.

Stratigraphic range: Upper Cretaceous (Santonian-Campanian); northwestern part of the Pacific Ocean, Holes 196 and 198Arelatively rare.

\section{Genus PSEUDOBOLIVINA Wiesner, 1931 \\ Pseudobolivina munda sp. nov. (Plate 2, Figures 10, 11)}

Holotype: N4011/16 (Figure 11); Hole 196, Core 2, Section 1 (107-109); paratype N 4011/17 (Figure 10); Hole 196, Core 2, Section 5 (129-131); Upper Cretaceous (Santonian-Campanian); Pacific Ocean.

Description: Test very small, wedge-shaped, elongate, slender, somewhat compressed from the lateral side, gradually tapering toward the base, pointed at the base. Periphery rounded, slightly lobulate. Chambers biserial, four to six in one row, rapidly increasing in size, trapeziform (broader than high) in the initial part, inflated, subsphaerical in the apertural part. Septal sutures straight, horizontal, depressed, and incised in the apertural part. The median suture is indistinctly zigzag. The aperture of immature forms a narrow symmetrical slit, perpendicular to the base of the apertural face and not reaching this base; the aperture of adult forms a circular terminal opening bordered by a thin lip (Figure 10) or a pronounced neck (Figure 11). Wall siliceous, smooth, glassy, semitransparent, very thin, and homogeneous (when magnified 150 times, no separate grains are visible). Dimensions: length $-0.17-0.20$ $\mathrm{mm}$; width of the apertural part $-0.07-0.10 \mathrm{~mm}$.

Remarks: A similar species-Pseudobolivina variabilis Vasicekhas been described from the Lower Cretaceous deposits of Czechoslovakia and Poland, but it differs by tightly united chambers, their trapeziform (not sphaerical) shape throughout the growth, and an aperture which is not encircled by a neck.

Stratigraphic range: Upper Cretaceous (Santonian-Campanian); northwestern part of the Pacific Ocean, Holes 196 and 198Acommon.

\section{Genus BOLIVINOPSIS Yakovlev, 1891}

The genus Bolivinopsis includes agglutinated foraminifera with a large circular planispiral initial part and a long, very narrow biserial part. The spire forms an incomplete volution around the proloculus. The diameter of the spiral part of microspheric specimens is less than the width (the largest) of the biserial stage; the diameter of the spiral part of megalospheric specimens is equal to, or exceeds slightly, the width of the biserial stage. A similar genus, Spiroplectammina Cushman, 1927, differs by the character of the initial planispiral part (the spire forms more than one whorl around the proloculus) and another ratio of dimensions between the planispiral and biserial stages (the diameter of the initial stage is considerably less than the width of the apertural end of a test). Many micropaleontologists also suggest that the genus Bolivinopsis should be distinguished from the genus Spiroplectammina by a calcareous wall, consisting of agglutinated fine-grained calcareous particles.

Taking into account the morphological peculiarities of textulariids in question found in zeolitic clays of Holes 196 and 198A, they should be assigned to the genus Bolivinopsis. But zeolitic clays were laid down well below the carbonate compensation depth and, naturally, calcareous particles in the wall of foraminifera studied are lacking (the wall is agglutinated siliceous). Thus, the feature of the composition of the wall (agglutinated calcareous or agglutinated siliceous), evidently, cannot be used for delimitation of representatives of the genus Bolivinopsis and the genus Spiroplectammina.

\section{Bolivinopsis parvissimus sp. nov. \\ (Plate 2, Figures 8, 9)}

Holotype: N4011/18 (Figure 9); Hole 196, Core 2, Section 5 (16-18); paratype N 4011/19 (Figure 8); Hole 198A, Core 4, Section 1 (116-118); Upper Cretaceous (Santonian-Campanian); Pacific Ocean.

Description: Test tiny, slender, elongated, compressed from the lateral sides, with a narrow rounded peripheral margin, consisting of the initial planispiral stage and later biserial stage. The planispiral part includes the proloculus and four to five successive subsphaerical chambers which form $3 / 4$ of a whorl or about one whorl. The biserial part consists of two rows of moderately convex, oval, equilateral (width and height are approximately equal) chambers. Every row numbers five to six chambers, slowly increasing in height as added. Chambers are separated by weakly depressed septal sutures arranged weakly obliquely (almost perpendicular) to the axis of the biserial stage. The median suture is slightly zigzag. The width of the apertural end exceeds insignificantly the width of the planispiral part, or is equal to it; therefore, the margins of the biserial stage are nearly parallel. The aperture is a low arch at the base of the apertural face. The wall is siliceous, smooth, glassy, and homogeneous; under a magnification of 150 times, it sometimes appears to consist of minute grains. Dimensions: length-0.20-0.26 $\mathrm{mm}$; width of the apertural end $-0.05-0.08 \mathrm{~mm}$.

Remarks: The species described differs clearly from the other Cretaceous species of Bolivinopsis by its tiny size and a homogeneous glassy wall. Taking into consideration the general shape of the test, there is a resemblance with B. capitata Yakovl., B. compta Finl., B. grzybowskii (Frizz.), B. rosula (Ehrenb.), but all these species are easily distinguished by numerous, narrow, obliquely arranged chambers. 
Stratigraphic range: Upper Cretaceous (Santonian-Campanian); northwestern part of the Pacific Ocean, Holes 196 and 198Acommon.

\section{Family TROCHAMMINIDAE}

Genus PRAECYSTAMMINA gen. nov.

Diagnosis: Test streptospiral (proloculus and initial whorl are not visible); chambers oval, hemisphaerical, few (4 on each side of test; last whorl contains three chambers); septal sutures depressed; aperture comprising oval slit in face of the last chamber, above and parallel to basal margin of this chamber (areal), bordered by thin lip or low neck; wall siliceous, smooth, glassy, homogeneous, and cryptocrystalline (?).

Type level and type locality: Upper Cretaceous, SantonianCampanian; northwestern part of the Pacific Ocean (Holes 196, 198A).

Type species: Praecystammina globigerinaeformis sp. nov.

Remarks: The new genus Praecystammina bears a morphologic similarity to some other genera of the family Trochamminidae: Cystamminella Mjatliuk, 1966; Cystammina Neymayr, 1889; Ammosphaeroidina Cushman, 1910; and Trochamminella Cushman, 1943.

The most significant resemblance is observed with the genus Cystamminella described by Mjatliuk (1966) from the Upper Cretaceous, Paleocene, and Eocene deposits of the Carpathians. This genus is also characterized by a test with few chambers $(3-4$ chambers are visible at exterior) and a cryptocrystalline wall, but the slit-like aperture is located at the base of the last chamber.

The genus Cystammina (Eocene-Recent) has the analogous slit-like aperture, arranged above the base of the last chamber and the finely agglutinated wall with considerable amount of cement. It differs from the genus Praecystammina gen. nov. by its high, inflated, elongate chambers; this attaches to the genus Cystammina a similarity to some representatives of calcareous Chilostomellidae (the junior synonym of Cystammina bears the name Ammochilostoma Eimer and Fickert, 1899, emphasizing the homeomorphic resemblance of these calcareous and agglutinated foraminifera).

The genus Ammosphaeroidina (Cretaceous-Recent) is distinguished from the genus Praecystammina gen. nov. by a globose test with three embracing chambers in the final whorl and a low arch-like aperture at the base of the last chamber.

The genus Trochamminella is characterized by the same areal aperture as the genus Praecystammina gen. nov., but is easily differentiated by its trochospiral test with numerous chambers on the spiral side.

\section{Praecystammina globigerinaeformis gen. et sp. nov.}

(Plate 2, Figures 1a,b,c, 2)

Holotype: N 4011/20 (Figures 1a,b,c); Hole 198A, Core 3 (core catcher); paratype N 4011/21 (Figure 2); Hole 198A, Core 4, Section 1 (138-140); Upper Cretaceous (Santonian-Campanian); Pacific Ocean.

Description: Test very small, globose, Globigerina-like. When looking from the side, the test is subtriangular, with broadly lobulate contour (three lobes); from the periphery, the test is oval, with a broadly rounded peripheral margin. Coiling of the initial whorls is evidently streptospiral-the proloculus and initial whorls are not visible on the outside. The last whorl contains three inflated, oval, hemisphaerical or reniform chambers. One side of the test is evolute; its central part is occupied by a large subtriangular chamber of the preceding whorl. The opposite side is weakly evolute; in its center a small portion of a chamber of the inner whorl is visible; sometimes, three chambers of the last whorl are united in the center, and this side of the test becomes completely involute. Septal sutures are depressed and weakly curved. The aperture is areal, slit-like or oval, near the inner margin of the last chamber but above and parallel to the base of this chamber, bordered by a thin lip or a low neck. The position of the aperture is not fixed in relation to the sides of the test; it is located more frequently on the evolute side than on the weakly evolute side. The wall is siliceous, smooth, glassy, homogeneous and cryptocrystalline (?); sometimes revealing a finely granular structure. Dimensions: diameter-0.15-0.27 mm; thickness $-0.12-0.18 \mathrm{~mm}$.
Remarks: Morphological features of this species are very constant. As it has been said above, the variable features are: the character of one side of the test (weakly evolute or involute); the position of the aperture (on the evolute or weakly evolute side); the form of the aperture (slit-like or oval, with a lip or a low neck).

Stratigraphic range: Upper Cretaceous (Santonian-Campanian); northwestern part of the Pacific Ocean, Holes 196 and 198Afrequent.

\section{Family AMMODISCIDAE}

Genus AMMODISCUS Reuss, 1862

Ammodiscus asperellus sp. nov.

(Plate 3, Figure 6)

Holotype: N 4011/22; Hole 196, Core 2, Section 5 (74-76); Upper Cretaceous (Santonian-Campanian); Pacific Ocean.

Description: Test medium sized, planispiral, consisting of a large proloculus and long tubular undivided second chamber, which forms $3 \frac{1}{2}$ to 4 whorls. The height of the whorl increases verh slowly in the process of coiling and is subject to variation (the tubular chamber forms inflations and constrictions). Each whorl slightly overlaps the previous one. Sutures between adjacent whorls are depressed and irregularly curved. The test is strongly compressed from the lateral sides, thin; when looking from the side, it has a circular contour. The aperture is formed by the open end of the tubular chamber. The wall is agglutinated, fine-grained, very thin (in a drop of water the wall becomes semitransparent, especially the proloculus). The surface is rough. Dimensions: diameter $-0.50-0.60 \mathrm{~mm}$; thickness0.06-0.08 mm.

Remarks: The finely agglutinated wall of this species differs distinctly from the siliceous, homogeneous, cryptocrystalline wall of those species of Haplophragmoides, Labrospira, Plectorecurvoides, Pseudobolivina, and Praecystammina which were encountered in zeolitic clays of Holes 196 and 198A.

The characteristic features of Ammodiscus asperellus (a very thin flattened test with the large proloculus, a small number of whorls of the irregular tubular second chamber) distinguish this species from many other Cretaceous species of Ammodiscus. A distant similarity is observed with A. kiowensis Loebl. and Tapp. (Lower Cretaceous of Kansas) and A. pennyi Cushm. and Jarv. (Upper Cretaceous of the Gulf Coast and Trinidad). The former differs in a greater number of whorls (5-6), more significant embracing of previous whorls, and small size (diameter up to $0.20 \mathrm{~mm}$ ); the latter, in a small number of whorls (2) of the regular tubular second chamber, and a thick wall with a broadly rounded periphery.

A very distant similarity is observed also with Ammodiscus gaultinus Berth. (owing to the irregular whorls of the tubular chamber). But in its development, this species passes the Glomospira-like initial stage and is now assigned to the genus Glomospirella.

Stratigraphic range: Upper Cretaceous (Santonian-Campanian); northwestern part of the Pacific Ocean, Holes 196 and 198A-rare.

\section{Genus GLOMOSPIRA Rzehak, 1885 \\ Glomospira charoides (Jones and Parker) (Plate 3, Figures 5a,b)}

1860. Trochammina squamata var. charoides Jones and Parker, p. 304.

Holotype: N 4011/23: Hole 196, Core 2, Section 1 (30-32), Upper Cretaceous (Santonian-Campanian); Pacific Ocean.

Description: Test small, trochospiral, consisting of a large proloculus and a long, undivided, tubular chamber. The proloculus is distinctly separated from the tubular chamber. The latter forms 3 to $3 \frac{1}{2}$ whorls of the spire. The height of the whorls remains practically unchanged throughout the coiling. The sutures between adjacent whorls are depressed. The semicircular aperture is formed by the open end of the tube. The wall is siliceous, thick, homogeneous (looks like the porcelaneous wall of milliolids). Dimensions: diameter $-0.22-0.23 \mathrm{~mm}$; thickness (along the axis of coiling) $-0.13-0.17 \mathrm{~mm}$.

Remarks: The tubular chamber of this species forms a regular low cone. The tube then enrolls in the opposite direction embracing the previous part. The test of such specimens consists of the "inner coil" and "outer coil." 
The species described bears a considerable resemblance to $G$. charoides, which is characterized by wide geographic and stratigraphic range.

Stratigraphic range: Upper Cretaceous (Santonian-Campanian); northwestern part of the Pacific Ocean, Holes 196 and 198Acommon.

\section{Family LITUOLIDAE (?)}

\section{Genus PARATROCHAMMINOIDES Soliman, 1972 (?)}

These peculiar, irregularly coiled forms were found in the Cretaceous zeolitic clays of Sites 196 and 198. Occasionally, the whorls form an irregular, trochospiral coil (Plate 3, Figures 3a,b,c); sometimes coiling approximately planispiral (Plate 3, Figures $4 \mathrm{a}, \mathrm{b}, \mathrm{c}$ ); and in other cases it is disordered and whimsical (Plate 3, Figures 1a,b,c, 2a,b,c).

Similar agglutinated foraminifera with irregularly coiled tests appear to be typical for the upper part of the Upper Cretaceous (Senonian); they have been described from Senonian deposits of Austria, Poland, Roumania, Czechoslovakia, Hungary, and the USSR (Carpathians). These species are usually attributed to the genus Trochamminoides: $T$. draco (Grzyb.), $T$, mitrata (Grzyb.), $T$. proteus (Karrer), T. uviformis (Grzyb.), T. elegans (Rzehak), etc. But the genus Trochamminoides is, as a rule, characterized by regular planispiral coiling, and the affinity of the above species with the genus Trochamminoides is doubtful.

Not long ago, H. Soliman (1972) introduced a new generic name-Paratrochamminoides-for representatives of Trochamminoides with irregular coiling (at all stages of development). The four species given below show most affinity with the genus Paratrochamminoides, but they differ abruptly in their siliceous, glassy, cryptocrystalline (secretional ?) wall which resembles the porcellaneous wall of miliolids. These species are, therefore, conditionally attributed to the genus Paratrochamminoides and the family Lituolidae.

\section{Paratrochamminoides (?) semipellucidus sp. nov.} (Plate 3, Figures 4a,b,c)

Holotype: N 4011/24; Hole 196, Core 2, Section 1 (107-109); Upper Cretaceous (Santonian-Campanian); Pacific Ocean.

Description: Test small to medium sized, consisting of three to four whorls in an irregular, very low trochoid spire. In some whorls, the coiling approximates to planispiral. When looking from the lateral side, the test is broadly oval; from the periphery, it looks narrowly oval, with a rounded peripheral margin. The whorls are tubular, relatively low, their height very slowly increasing in the process of coiling (in the last one or two whorls it remains practically constant). The whorls are subdivided into tubular chambers (4-6 in the last whorls); their length within one whorl varies greatly. The septal sutures are slightly depressed, indistinct, thin, and straight. The sutures between adjacent whorls are distinct and depressed. The central parts of lateral sides are occupied by flat umbilical deepenings. The aperture is the open end of the tube. The wall is siliceous, cryptocrystalline, glassy, smooth, and very thin; when moistened, it becomes semitransparent. Dimensions: diameter0.35-0.45 mm; thickness-0.19-0.23 mm.

Remarks: The characteristic features of the species are as follows: low trochospiral coiling which is close to planispiral; a very thin, smooth, semitransparent wall; an irregular septation of tubular whorls and indistinct septal sutures. The last feature gives to Paratrochamminoides (?) semipellucidus sp. nov. a distant similarity with representatives of the genus Ammodiscus.

Stratigraphic range: Upper Cretaceous (Santonian-Campanian); northwestern part of the Pacific Ocean, Holes 196 and 198Acommon.

\section{Paratrochamminoides (?) corpulentus sp. nov.} (Plate 3, Figures 3a,b,c)

Holotype: N 4011/25; Hole 196, Core 2, Section 1 (18-20); Upper Cretaceous (Santonian-Campanian); Pacific Ocean.

Description: Test small or medium sized, formed by some whorls of the irregular, relatively low trochoid spire. The early part is knot-shaped (the proloculus and the initial whorl are not visible). The last $1 \frac{1}{2}$ to 2 whorls constitute a relatively regular trochoid spire.
When looking from the lateral sides, the test is broadly oval; from the periphery, the test looks like a low truncated cone, peripheral margin is broadly rounded. The whorls are tubular, rather high, their height slowly increasing in the process of coiling. The last whorl is separated into five to six oval, convex chambers; their length in limits of the last whorl is unstable. The septal sutures are distinctly depressed, slightly oblique; the sutures between whorls are also depressed. The central parts of the lateral sides are occupied by convex knot-shaped whorls and umbilical deepenings are absent. The aperture is an open end of the tube, large and semicircular. The wall is siliceous, glassy, smooth, cryptocrystalline (?), and thick, but on moistening with water it becomes semitransparent. Dimensions: diameter (the largest) $-0.40-0.47 \mathrm{~mm}$; thickness $-0.25-0.30 \mathrm{~mm}$.

Remarks: The species under consideration is distinguished from Paratrochamminoides (?) semipellucidus sp. nov. by tight irregular coiling, a thick wall, convex chambers, depressed septal sutures, and the absence of umbilical deepenings.

Stratigraphic range: Upper Cretaceous (Santonian-Campanian); northwestern part of the Pacific Ocean, Holes 196 and 198A-rare.

Paratrochamminoides (?) vitreus sp. nov. (Plate 3, Figures 1a,b,c)

Holotype: N 4011/26; Hole 196, Core 2, Section 2 (73-75); Upper Cretaceous (Santonian-Campanian); Pacific Ocean.

Description: Test small, knot-shaped. When looking from the lateral sides, the test is broadly oval, with a lobulate contour; from the periphery, it is irregularly oval, with broadly rounded peripheral margin. One side of the test is strongly convex, the opposite side is flattened. Coiling of initial whorls is very irregular, knot-shaped; proloculus not visible. The last tubular whorl forms a low trochoid spire, of nearly constant height. This whorl is usually subdivided into six chambers of unequal length, oval or sphaerical, convex. Septal sutures are depressed, almost straight; sutures between adjacent whorls are distinct, depressed. Umbilical deepenings are absent. The aperture is formed by an open end of the tubular chamber, oval or rounded; the diameter of the aperture is more narrow as compared to that of the tube. The wall is siliceous, glassy, smooth, cryptocrystalline (?), very thin, and semitransparent (even without moistening by water). Dimensions: diameter (the largest)$0.25-0.35 \mathrm{~mm}$; thickness $-0.14-0.18 \mathrm{~mm}$.

Remarks: The species described is similar to Paratrochamminoides (?) corpulentus sp. nov., distinguished by smaller size, a fragile thin-walled test, semitransparent wall, and rounded aperture.

Stratigraphic range: Upper Cretaceous (Santonian-Campanian); northwestern part of the Pacific Ocean, Holes 196 and 198A-rare.

\section{Paratrochamminoides (?) intricatus sp. nov.}

(Plate 3, Figures 2a,b,c)

Holotype: N 4011/27; Hole 198A, Core 4, Section 1 (116-118); Upper Cretaceous (Santonian-Campanian); Pacific Ocean.

Description: Test medium-sized, irregularly coiled, knot-shaped, with irregular outline. The initial stage, apparently, is trochospiral (or irregularly trochospiral). The last whorl of the trochospiral stage contains five to six subspherical convex chambers, separated by depressed straight septal sutures. The central part of the ventral side (of the trochospiral stage) is occupied by a relatively deep umbilicus (Figure 2b). The tubular spire of the later stage of coiling changes its direction and stretches over the dorsal side of the test and then to the ventral side again. Thus, planes of coiling of the trochospiral and later irregular stages form an angle of about $90^{\circ}$. This part of the tubular spire (on the dorsal side) numbers five to six chambers of subsphaerical, convex shape separated by depressed, straight septal sutures. The height of the whorl increases very slowly in the process of coiling. The aperture looks like a relatively low arch at the base of the convex apertural surface, that distinctly differentiates $P$. (?) intricatus sp. nov. from the other species of the genus Paratrochamminoides mentioned in this chapter. The wall is siliceous, cryptocrystalline (?), smooth, glassy, and thin. Dimensions: diameter (the largest) $-0.45-0.44 \mathrm{~mm}$; thickness $-0.25-0.30 \mathrm{~mm}$.

Remarks: Taking into account the character of coiling, the species concerned has a similarity with some previously described species of Paratrochamminoides $-P$. mitrata (Grzyb.), $P$. draco (Grzyb.), but the latter differ strongly by their large dimensions (up 
to $1.5-2.0 \mathrm{~mm}$ ) and a distinctly grainy agglutinated wall with a rough surface.

Stratigraphic range: Upper Cretaceous (Santonian-Campanian); northwestern part of the Pacific Ocean, Holes 196 and 198Arelatively common.

\section{REFERENCES}

Alekseichik-Mizkevich, L. S., Subbotina, N. N., Baranovskaya O. F., Bulatova, Z. I., Bulinnikova, S. P., Dubrovskaya, N. F., et al., 1964. Foraminifera of the Cretaceous and Paleogene deposits of the West-Siberian lowland: Trans. VNIGRI, v.234 (in Russian).

Bukalova, G. V., 1957. The new genus of foraminifera from the Albian deposits of the northwestern Caucasus: Trans. USSR Acad. Sci., v. 114, no. 1 (in Russian).

Crespin, I., 1953. Lower Cretaceous foraminifera from the Great Artesian Basin, Australia: Contr. Cushm. Found. Foram. Res., v. 4, no. 1.

1963. Lower Cretaceous arenaceous foraminifera of Australia: Bur. Min. Res. Geol. Geophys. Bull. no. 66.

Cushman, J., 1946. Upper Cretaceous foraminifera of the Gulf Coastal region of the United States and adjacent areas: U. S. Geol. Surv., Prof. Paper, 206.

Cushman, J., Deaderick, W., 1944. Cretaceous foraminifera from the Marlbrook marl of Arkansas: J. Paleont., v.18, no. 4 .

Cushman, J., Jarvis, P., 1932. Upper Cretaceous foraminifera from Trinidad: Proc. U.S. Nat. Mus., v.80, no. 14

Douglas, R. and Moullade, M., 1972. Age of the basal sediments on the Shatsky Rise, western North Pacific Ocean: Am. Assoc. Petrol. Geol., Bull.

Fischer, A. G., Heezen, B. C., Boyce, R. E., Bukry, D., Douglas, R. G., Garrison, R. E., Kling, S. A., Krasheninnikov, V.A., Lisitzin, A.P., and Pimm, A.C., 1970. Initial Reports of the Deep Sea Drilling Project, Volume VI: Washington (U.S. Government Printing Office).

Frizzel, D. L., 1954. Handbook of Cretaceous foraminifera of Texas: Bur. Econ. Geol. (Austin), Rept. 22.

Galloway, S. and Morrey, M., 1931. Late Cretaceous foraminifera from Tabasco, Mexico: J. Paleont., v.5, no. 4.

Geroch, S., 1960. Microfaunal assemblages from the Cretaceous and Paleogene Silesian unit in the Beskid Slaski Mountains. Inst. Geol., Bull. v.153.

1962. Thalmannammina and Plectorecurvoides (Foraminifera) in the Lower Cretaceous of the Flysch Carpathians: Ann. Soc. Geol. Pologne, v.32, no. 1-2. 1966. Lower Cretaceous small foraminifera of the Silesian Series, Polish Carpathians: Ann. Soc. Geol. Pologne, v.36, no. 4.

Gorbachik, T. N., 1971. Lower Cretaceous of the Crimea. In Guide book of the XII European Micropaleontological Colloquium: USSR, 1971.

Hanzlikova E., 1969. The Foraminifera of the Frydek Formation (Senonian); Sborn. Geol. Věd, R. P., v. 11.

1972. Carpathian Upper Cretaceous foraminiferida of Moravia (Turonian-Maastrichtian): Rozpr. U U G, sv. 39.
1973. Foraminifers of the Variegated Godula Member in Moravia (Cenomanian-Turonian). Sborn. Geol. Věd, Paleont., Rada P, sv. 15.

Loeblich, A. R. and Tappan, H., 1964. Treatise on invertebrate paleontology: Sarcodina, chiefly "Thecamoebians" and Foraminiferida: Pt. C Protista (2), Geol. Soc. Am.

Mjatliuk, E. V., 1966. On the foraminifera with a siliceous skeleton: Questions of Micropaleontology, no. 10 (in Russian).

1970. Foraminifera of the flysh sediments of the Eastern Carpathians: Trans. VNIGRI, v.282 (in Russian).

Neagu, T., 1962. Studiul foraminiferol aglutinante din argilete Cretacic superioare de pe Valea Sadovei si bazinul superior al vaii Buzuului: Stud. Cerc. Geol. Geophys. Geogr., Ser. Geol., v. 7.

1968. Biostratigraphy of Upper Cretaceous deposits in the southern eastern Carpathians near Brasov: Micropaleontology, v. 14.

1970. Micropaleontological and stratigraphical study of the Upper Cretaceous deposits between the upper valleys of the Buzau and Riul rivers (eastern Carpathians): Inst. Geol. Mem., v. 12.

Noth, R., 1951. Foraminiferen aus Under- und Oberkreide des österreichischen Anteils an Flysch Helvetikum und Vorlandvorkommen: Jahrb. Geol. Bundesanst. (Wien), Sonderb. 3.

1952. Plectorecurvoides eine neue foraminiferengattung: Verhandl. Geol. Bundesanst., no. 3.

Orlov, Yu. A. (Chief Ed.), Rauser-Chernousova, D. M., Fursenko, A. V. (Eds.) 1959. Treatise on Paleontology: v.1, Protozoa, Moscow (in Russian).

Plotnikova, L. F., 1967. The shallow-water Upper Cretaceous foraminifera of the platform part of the Ukrainian SSR: Kiev (in Ukrainian).

Podobina, V. M., 1966. Foraminifera of the Upper Cretaceous of the western Siberian lowland: Moscow (in Russian).

Scheibnerova, V., 1961. Mikrofauna strednej a vrchnej kriedy bradloveho pasma zapad Karpat na Slovensku: Acta Geol. Geogr. Univ. Comen., v. 5.

1968. Middle and Upper Cretaceous microbiostratigraphy of the Klippen Belt (West Carpathians): Acta Geol. Geogr. Univ. Comen., v. 17.

Sliter, W. V., 1968. Upper Cretaceous foraminifera from Southern California and northwestern Baja California, Mexico: Univ. Kansas Paleont. Contrib., Ser. no. 49.

Soliman, H. A., 1972. New Upper Cretaceous foraminifera from the Soviet Carpathians (USSR): Rev. Micropaléont., v. 15 , no. 1.

Takayanagi, Y., 1960. Cretaceous foraminifera from Hokkaido, Japan: Sci. Rept. Tohoku Unit., Sendai, Japan, ser. 1, v. 32, no.,1.

Tappan, H., 1957. New Cretaceous index foraminifera from northern Alaska: U. S. Nat. Mus., Bull., v.215.

Trujillo, E., 1960. Upper Cretaceous foraminifera from near Redding, Shasta County, California: J. Paleont., v.34, no. 2 .

Yoshida, S., 1963. Upper Cretaceous foraminifera from the Nemuro group, eastern Hokkaido, Japan: J. Hokkaido Gakugei Univ., v. 13, no. 2. 


\section{PLATE 1}

All magnifications 150 times; $\mathrm{a}=$ view from the lateral side; $b=$ view from the peripheral margin

Figures 1,2 Haplophragmoides multicamerus sp. nov.

1. Holotype: N4011/1; 196-2-1,38-40 cm.

2. Paratype: N 4011/2;198A-3-6, 90-92 cm; northwestern part of the Pacific Ocean; Upper Cretaceous (Santonian-Campanian).

Figures 3,4 Haplophragmoides biumbilicalis sp. nov.

3. Holotype: N 4011/5, 198A-3, CC.

4. (view from the lateral side) Paratype: $N 4011 / 6$; 198A-3-6, 90-92 cm; northwestern part of the Pacific Ocean; Upper Cretaceous (Santonian-Campanian).

Figure 5 Haplophragmoides constrictus sp. nov. Holotype: N 4011/4; 196-2-1, 30-32 cm; northwestern part of the Pacific Ocean: Upper Cretaceous (Santonian-Campanian).

Figure 6 Haplophragmoides perexplicatus sp. nov. Holotype: N 4011/8; 198A-4-2, 140-142 cm; northwestern part of the Pacific Ocean; Upper Cretaceous (Santonian-Campanian).

Figure $7 \quad$ Haplophragmoides pervagatus sp. nov. Holotype: N 4011/7; 196-2-1, 64-66 cm; northwestern part of the Pacific Ocean; Upper Cretaceous (Santonian-Campanian).

Figure $8 \quad$ Haplophragmoides molestus sp. nov.

Holotype: N 4011/9; 198A-4-1, 138-140 cm; northwestern part of the Pacific Ocean; Upper Cretaceous (Santonian-Campanian).

Figure 9 Haplophragmoides fraudulentus sp. nov. Holotype: N4011/3; 196-2-1, 18-20 cm; northwestern part of the Pacific Ocean; Upper Cretaceous (Santonian-Campanian). 


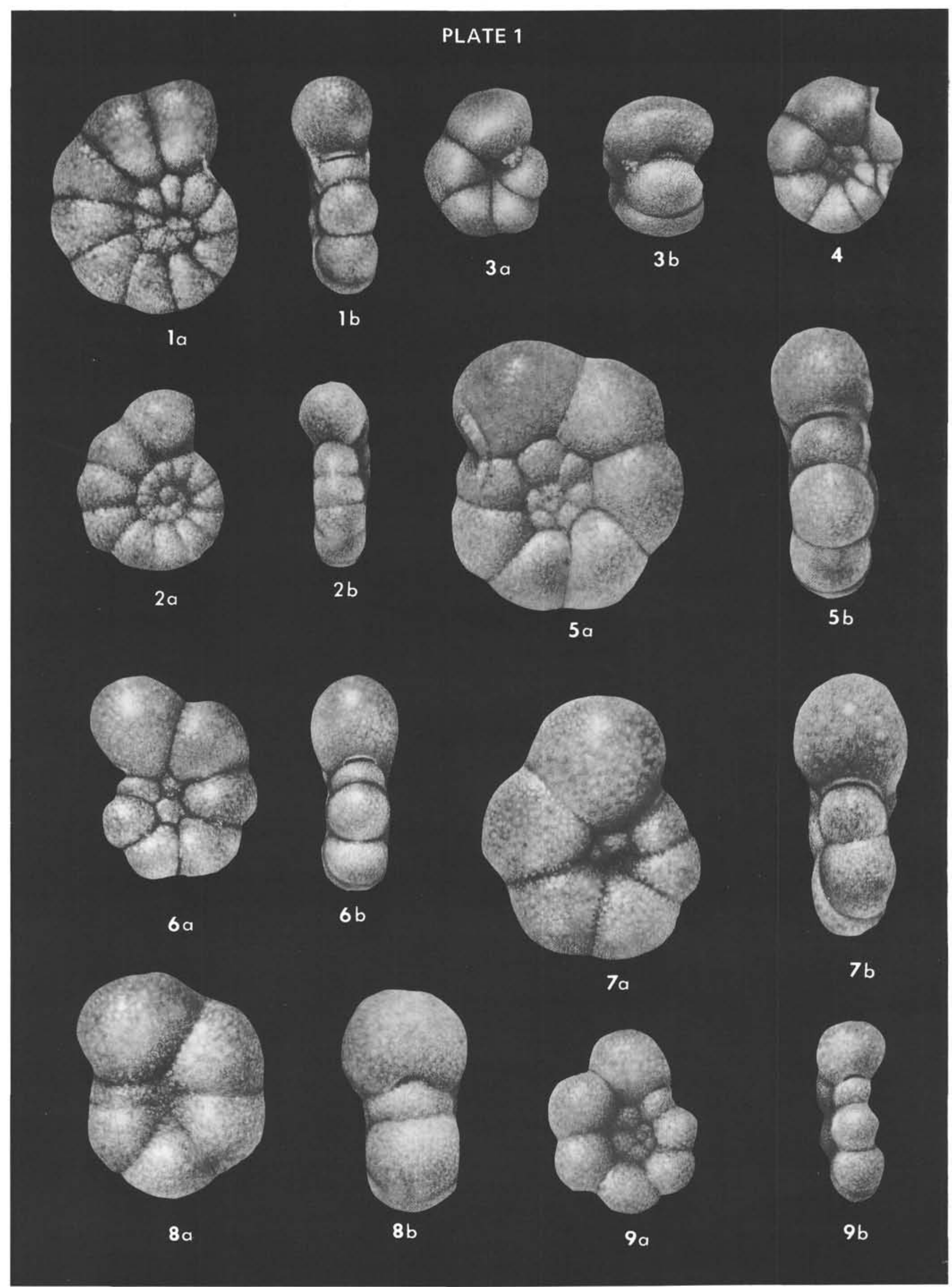




\section{PLATE 2}

All magnifications 150 times

Figures 1,2 Praecystammina globigerinaeformis gen. et sp. nov.

1. Holotype: N 4011/20; 198A-3, CC, (a, b-view from sides, $\mathrm{c}-$ view from the peripheral margin).

2. Paratype: N 4011/21; 198A-4-1, 138-140 cm; view from the apertural side, northwestern part of the Pacific Ocean; Upper Cretaceous (SantonianCampanian).

Figure 3 Haplophragmoides decussatus sp. nov. Holotype: N 4011/10; 196-2-2, 122-124 cm; a-view from the lateral side, $b$-view from the peripheral margin; northwestern part of the Pacific Ocean; Upper Cretaceous (Santonian-Campanian).

Figures 4, 5 Labrospira pacifica sp. nov.

4. Holotype: N 4011/12;196-2-1, 107-109 cm.

5. Paratype: N 4011/13; 198A-4-1, 116-118 cm; $a$-view from the lateral side, $b$-view from the peripheral margin; northwestern part of the Pacific Ocean; Upper Cretaceous (Santonian-Campanian).

Figures 6, $7 \quad$ Plectorecurvoides parvus sp.nov.

6. Paratype: N 4011/14; 198A-4-1, 138-140;

7. Holotype: $\mathrm{N} 4011 / 13,196-2-5,74-76 \mathrm{~cm}$.

a-view from the peripheral margin (the side is opposite to the apertural side), b-view from the lateral side, $\mathrm{c}$-view from the peripheral margin (on the apertural side); northwestern part of the Pacific Ocean; Upper Cretaceous (Santonian-Campanian).

Figures 8,9 Bolivinopsis parvissimus sp. nov.

8. Paratype: N 4011/19; 198A-4-1, 116-118 cm; view from the lateral side; northwestern part of the Pacific Ocean; Upper Cretaceous (SantonianCampanian).

9. Holotype: N 4011/18; 196-2-5, 16-18 cm.

Figures 10,11 Pseudobolivina munda sp. nov.

10. Paratype: N 4011/17; 196-2-5, 129-131 cm; view from the lateral side; northwestern part of the Pacific Ocean; Upper Cretaceous (Santonian-Campanian). 11. Holotype: N 4011/16; 196-2-1, 107-109 cm.

Figure 12 Haplophragmoides breviculus sp. nov.

Holotype: N 4011/11; 198A-3-6, 90-92 cm; a-view from the lateral side, $b$-view from the peripheral margin; northwestern part of the Pacific Ocean; Upper Cretaceous (Santonian-Campanian). 


\section{PLATE 2}

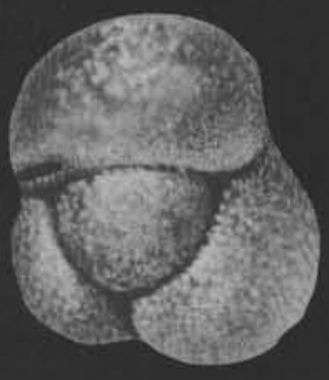

la
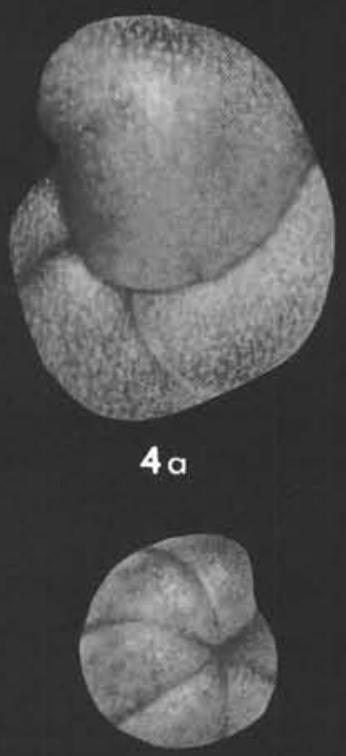

$12 a$

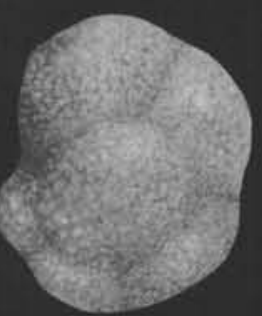

$6 a$

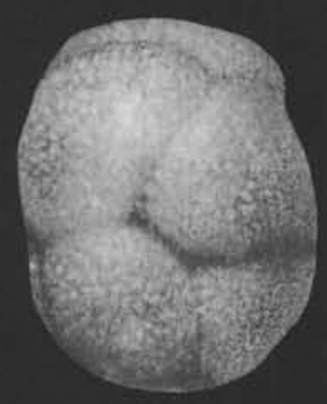

$7 a$
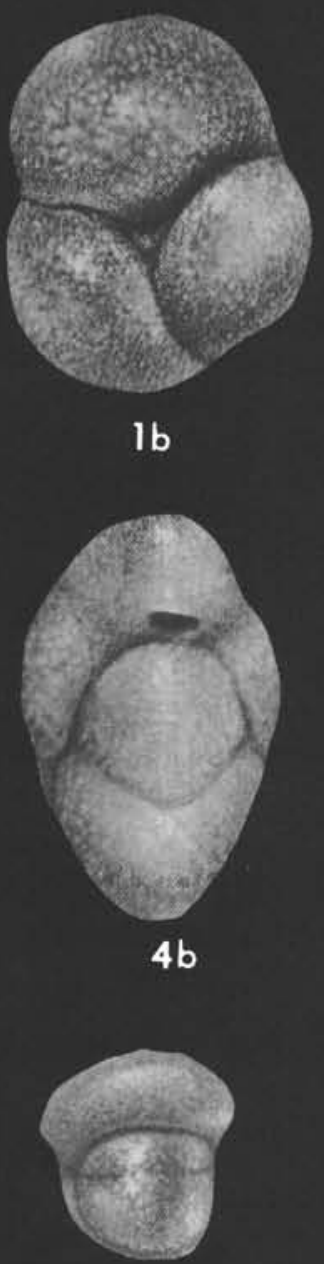

$12 \mathrm{~b}$
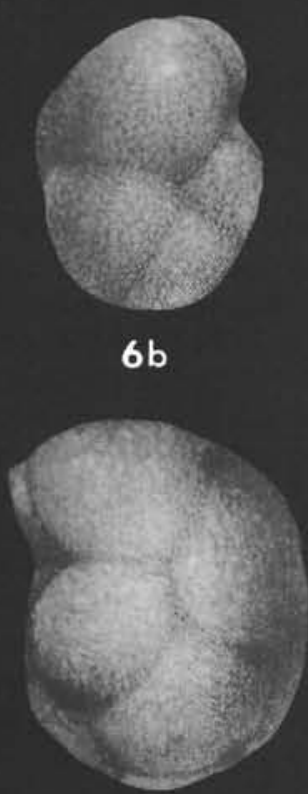

$7 b$

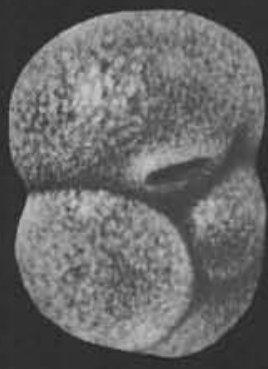

lc
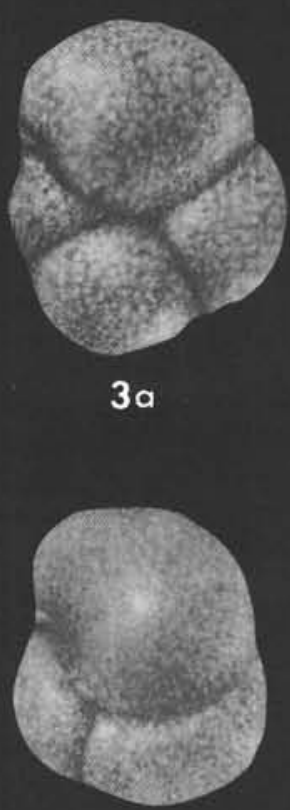

$5 a$
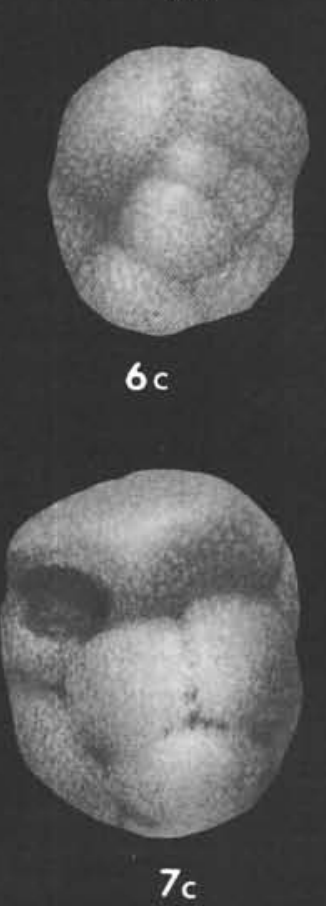
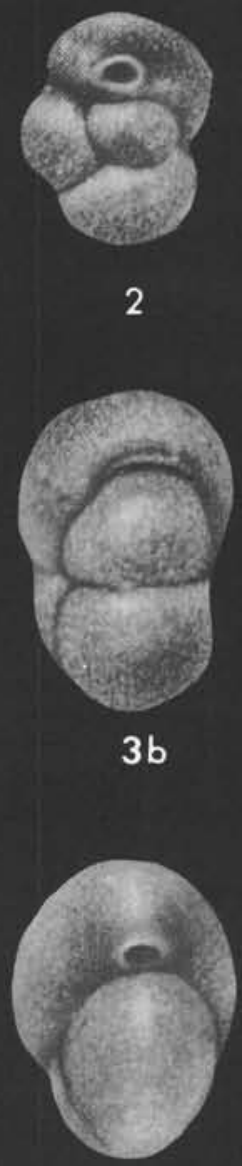

$5 b$
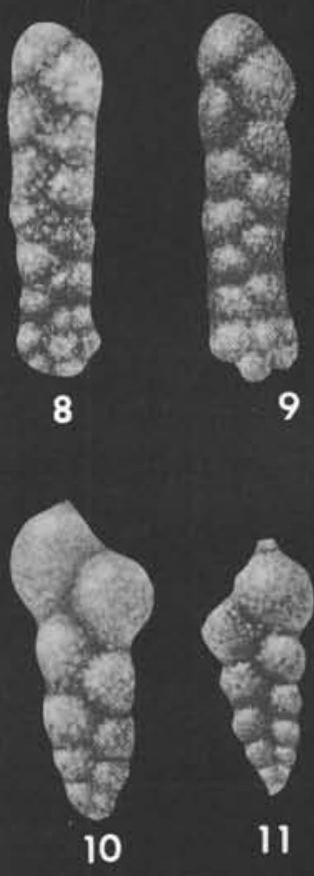


\section{PLATE 3}

Magnifications: Figures 1, 5-150 times;

Figures 2, 3, 4-100 times; and

Figure 6-75 times

Figure 1

Figure 2

Figure 3

Figure 4

Figure 5

Figure 6
Paratrochamminoides (?) vitreus sp. nov. Holotype: N 4011/26; 196-2-2, 73-75 cm; a,b-view from the sides, $c$-view from the peripheral margin; northwestern part of the Pacific Ocean; Upper Cretaceous (Santonian-Campanian).

Paratrochamminoides (?) intricatus sp. nov. Holotype: N 4011/27; 198A-4-1, 116-118 cm; a, $\mathrm{b}$-view from the sides, $\mathrm{c}$-view from the peripheral margin; northwestern part of the Pacific Ocean; Upper Cretaceous (Santonian-Campanian).

Paratrochamminoides (?) corpulentus sp. nov.

Holotype: N 4011/25; 196-2-1, 18-20 cm; a,b-view from the sides, $\mathrm{c}$-view from the peripheral margin; northwestern part of the Pacific Ocean; Upper Cretaceous (Santonian-Campanian).

Paratrochamminoides (?) semipellucidus sp. nov. Holotype: N 4011/24; 196-2-1, 107-109 cm; $\mathrm{a}, \mathrm{b}$-view from the sides, $\mathrm{c}$-view from the peripheral margin; northwestern part of the Pacific Ocean; Upper Cretaceous (Santonian-Campanian).

Glomospira charoides (Jones and Parker).

Holotype: N 4011/23; 196-2-1, 30-32 cm; a-view from the spiral side, $b$-view from the peripheral margin; northwestern part of the Pacific Ocean; Upper Cretaceous (Santonian-Campanian).

Ammodiscus asperellus sp. nov.

Holotype: N 4011/22; 196-2-5, $74-76 \mathrm{~cm}$; view from the lateral side; northwestern part of the Pacific Ocean; Upper Cretaceous (Santonian-Campanian). 
PLATE 3

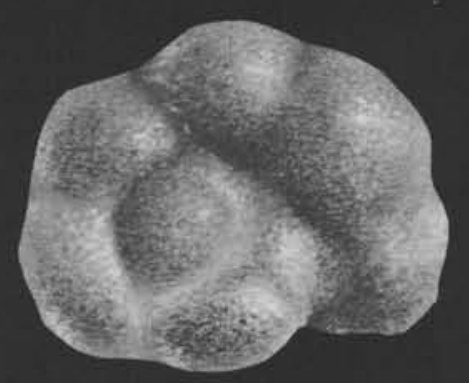

la

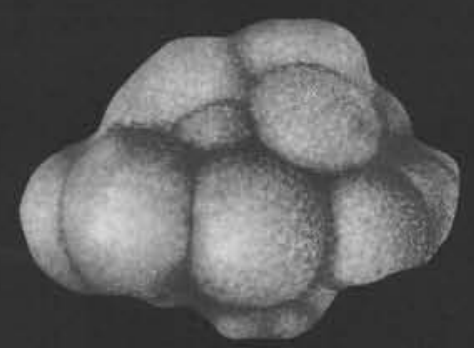

$2 a$

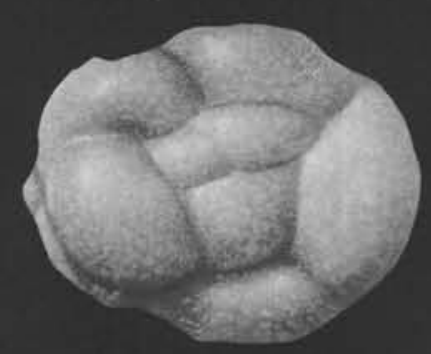

$3 a$

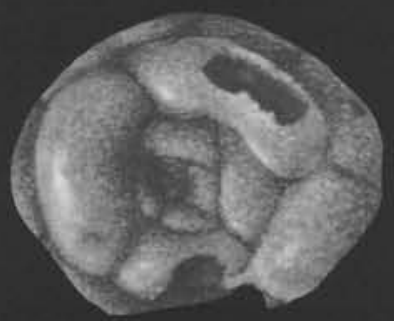

$4 a$

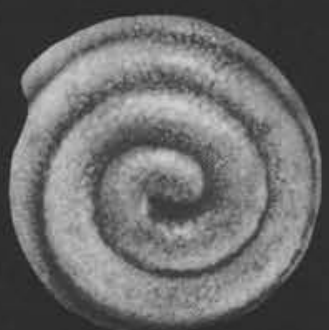

$5 \mathbf{a}$
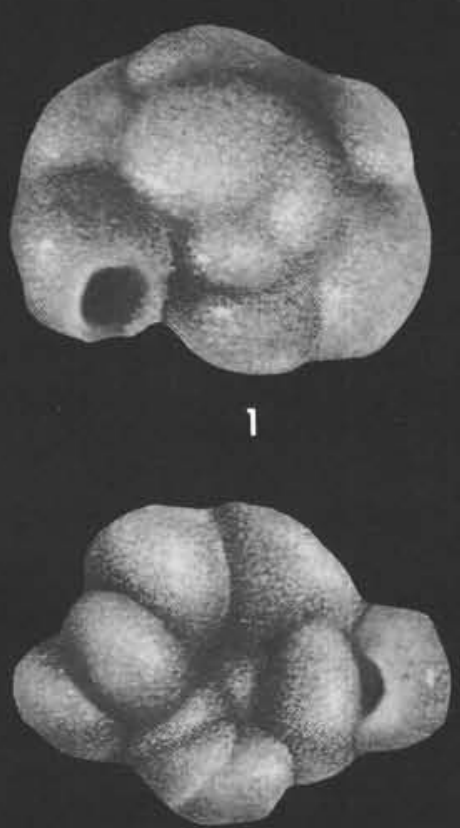

$2 b$
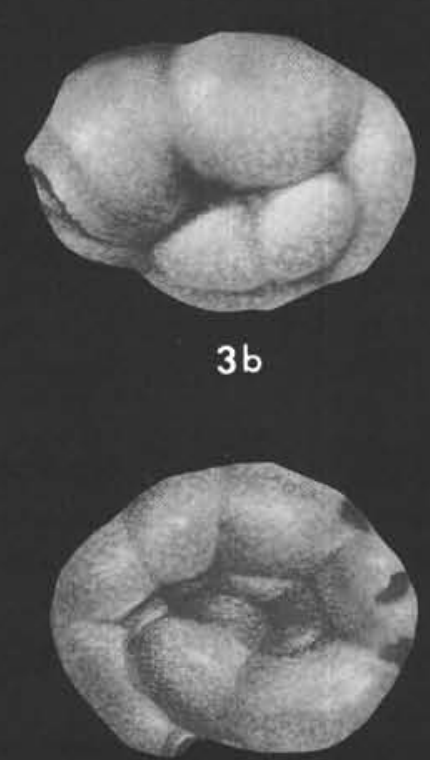

$4 b$

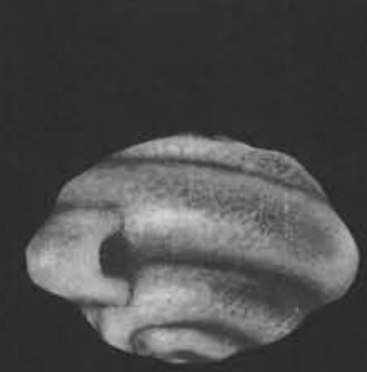

$5 b$
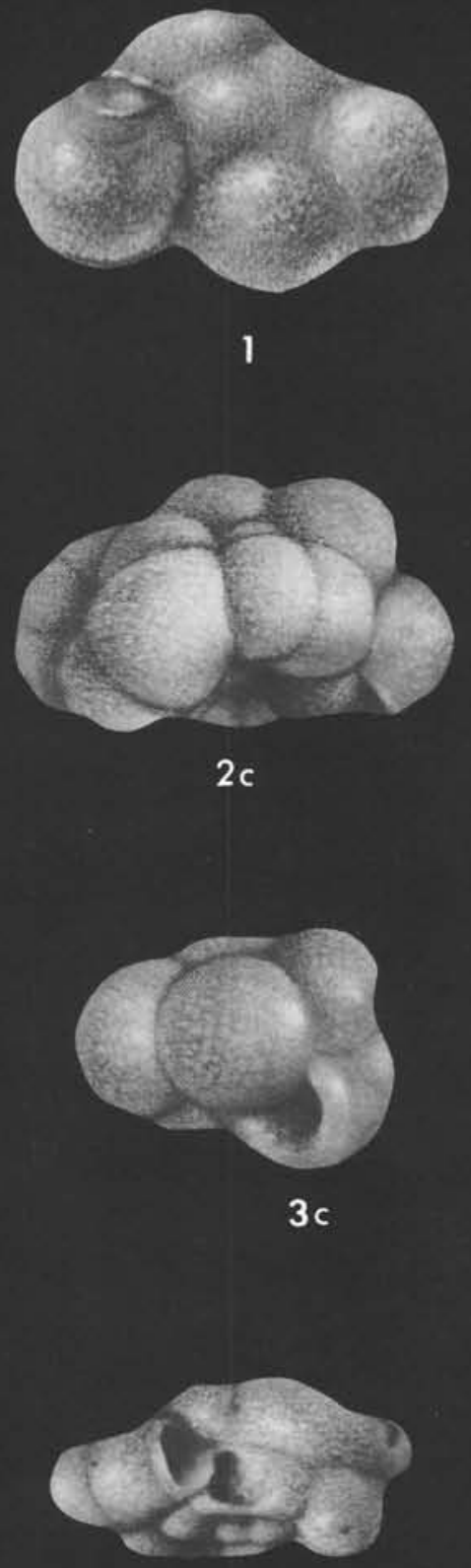

$4 c$

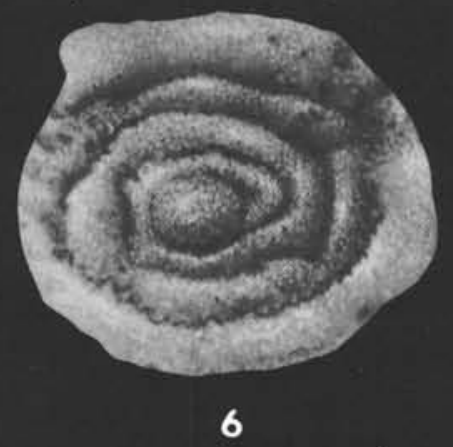

